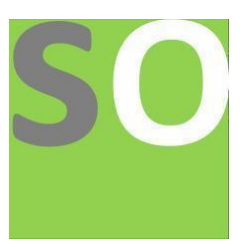

Article title: Fiber Separation From Wood Pulp Using Slider Crank Mechanism

Authors: MEIARUL RAJENDRAN[1]

Affiliations: Mechanical Engineering Department, Anand Institute of Higher Technology, Kalasalingam Nagar IT Corridor, Old Mahabalipuram Road, Kazhipattur, Tamil Nadu 603 103, India.[1]

Orcid ids: 0000-0003-4387-7091[1]

Contact e-mail: meiarulr@gmail.com

License information: This work has been published open access under Creative Commons Attribution License http://creativecommons.org/licenses/by/4.0/, which permits unrestricted use, distribution, and reproduction in any medium, provided the original work is properly cited. Conditions, terms of use and publishing policy can be found at https://www.scienceopen.com/.

Preprint statement: This article is a preprint and has not been peer-reviewed, under consideration and submitted to ScienceOpen Preprints for open peer review.

DOI: 10.14293/S2199-1006.1.SOR-.PPQKZZJ.v1

Preprint first posted online: 24 September 2021

Keywords: raw material, slider crank mechanism, de-fiberized, wood pulp, napkins 


\title{
FIBER SEPERATION FROM WOOD PULP USING SLIDER CRANK MECHANISM
}

\author{
Meiarul $\mathrm{R}^{1 *}$ \\ ${ }^{1}$ Mechanical Engineering Department, Anand Institute of Higher Technology, Kalasalingam Nagar IT Corridor, Old \\ Mahabalipuram Road, Kazhipattur, Tamil Nadu 603 103, India. \\ E-mail: $\underline{\text { meiarulr@gmail.com }}$
}

\begin{abstract}
The Fiber separating machine is used to separate the fibers from their raw material (wood pulp). The machine is based on slider crank mechanism in this an iron disk is mounted to the electrical motor. A slider with a rough tooth is present in its bottom. By using the connecting rod, the disk and slider are connected together. The connecting rod converts the rotary motion into the linear motion. By using the forward and backward motion the fibers are de fiberized from the raw material (wood pulp). This machine is used for small scale industries where bulk machines are not required. The main application of this wood pulp fiber is the making of napkins.
\end{abstract}

Key words: raw material, slider crank mechanism, de - fiberized, wood pulp, napkins.

\section{INTRODUCTION}

Non-Woven is a sheet, web (or) fabric like materials made from stable fiber (short) that have not been converted into yarns (thread) which are bonded together by means of mechanical, chemical, heat (or) solvent method. It is also called as "shaped fabrics" (or) "yarn - free fabrics" and it is used in textile manufacturing industry, medical and automobile and many other industries. Where, it is cost-effective and bio-degradable. There are different types of non - woven process namely, air laid \& wet laid process, spun bonding, melt blowing and finally needle binding process. Where, the fibers are produced by the use of sharp teeth fruit peeler following the slider crank mechanism. In this process an electrical motor which runs on AC power is mounted on the rigid base and a solid circular disc is fixed to the motor and sharp teeth peelers made up of stainless steel are arranged in parallel together to form a comb like structure are connected to the circular disc by the help of connecting rod through nuts and bolts. In which the fiber is produced from the wood pulp by the action of peeler connected to the motor. The produced fiber has the following properties like, Absorbency, Bacterial barrier, Filtering, Flame-retardancy, Liquid-repellency and softness etc. and it can be used for many applications like, Air bags, Car roofs and seat covers, Insulation for roofs and tiles, Thermal and acoustic 
insulation, Pots for bio-degradable plants, Materials for capillary irrigation, Coffee and tea bags, Protections for shock absorbers, Odour control, HEVA/HEPA/ULPA filters, Filters for liquids: oil, beer, milk, refrigerant liquids, fruit juices etc.

\section{A. SPECIFICATIONS OF MOTOR}

\begin{tabular}{ll}
\hline PARAMETER & VALUES \\
\hline RATED VOLTAGE & $230 \mathrm{~V}$ \\
\hline FREQUENCY & $50 \mathrm{~Hz}$ \\
\hline RATED CURRENT & $1.5 \mathrm{Amps}$ \\
\hline RATED POWER & $150 \mathrm{~W}$ \\
\hline RATED SPEED & $1300 \mathrm{Rpm}$ \\
\hline TYPE & CSR \\
\hline DUTY & S2 60 Min \\
\hline INSULATION & $\mathrm{F}^{1}$ class \\
\hline EFFICIENCY & $50 \%$ Nominal \\
\hline CAPACITOR & $8 \mathrm{MFD}$ \\
\hline
\end{tabular}

Table 1.1 Motor Specifications

\section{EXPERIMENTAL}

\subsection{FORMULA USED}

1. Bending moment, $\mathrm{M} / \mathrm{I}=\sigma_{b / Y}$

Where, $\sigma_{b}=\mathrm{M} \times \mathrm{Y} / \mathrm{I}\left(\mathrm{N} / \mathrm{m}^{2}\right)$

2. Area Moment Of Inertia $(\mathrm{I})=\mathrm{b} \times d^{3} / 12\left(\right.$ RECTANGLE) $\left(\mathrm{m}^{4}\right)$

3. Center Distance $(\mathrm{Y})=$ Thickness $/ 2(\mathrm{~m})$

$\sigma_{b}=$ bending moment, $\mathrm{N} / \mathrm{m}^{2}$

$\mathrm{M}=$ moment, $\mathrm{N} / \mathrm{m}$

$\mathrm{b}=$ breadth, $\mathrm{m}$

$\mathrm{d}=$ depth, $\mathrm{m}$

$\mathrm{Y}=$ center distance, $\mathrm{m}$ 


\subsection{DESIGN CALCULATION}

\section{For Connecting Rod (Rectangular Bar)}

\section{Bending Moment,}

$$
\begin{aligned}
& \mathrm{M} / \mathrm{I}=\sigma_{b / \mathrm{Y}} \\
& \sigma_{b}=\mathrm{M} \times \mathrm{Y} / \mathrm{I}
\end{aligned}
$$

Area Moment Of Inertia $(\mathrm{I})=\mathrm{B} \times d^{3} / 12$ (Rectangle)

$$
\begin{aligned}
& \mathrm{I}=(30) \times\left(6^{3}\right) / 12 \\
& \mathrm{I}=540 \mathrm{~mm}^{4}=0.54 \mathrm{~m}^{4}
\end{aligned}
$$

Breadth $(B)=30 \mathrm{~mm}=0.03 \mathrm{~m}$

Depth $(\mathrm{D})=6 \mathrm{~mm}=0.006 \mathrm{~m}$

Center Distance $(\mathrm{Y})=$ Thickness $/ 2$

$$
\begin{aligned}
& Y=6 / 2 \\
& Y=3 \mathrm{~mm}=0.003 \mathrm{~m}
\end{aligned}
$$

\section{To Find Moment (M),}

Let Us Consider,

The Connecting Rod As Uniformly - Distributed Load (UDL), Due To Both Ends Is Fixed.

Total Length $(\mathrm{L})=400 \mathrm{~mm}=0.4 \mathrm{~m}$

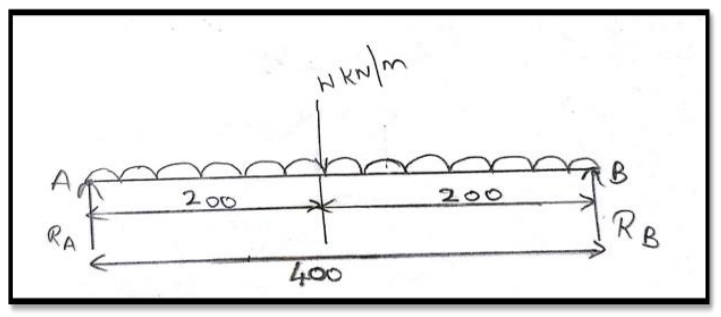

Figure. 1: UDL load

Density $(\mathrm{P})=$ Mass $/$ Volume

Mass $(\mathrm{M})=\mathrm{P} * \mathrm{~A} * \mathrm{~L}$

$\operatorname{Area}(\mathrm{A})=\mathrm{L} \times \mathrm{B}$

$\mathrm{A}=0.03 \times 0.4=0.012 \mathrm{~m}^{2}$ 
Density of the Mild Steel $(\mathrm{P})=7850 \mathrm{Kg} / \mathrm{m}^{3}$

Mass $(\mathrm{M})=7850 \times 0.012 \times 0.4$

Mass $(\mathrm{M})=37.68 \mathrm{Kg} / \mathrm{m}^{3}$

To Convert UDL to Point Load,

Weight of the UDL $(\mathrm{W})=37.68 \times\left(9.81 \times 10^{3}\right)$

$\mathrm{W}=3.69 \times 10^{5} \mathrm{KN} / \mathrm{m}$

Point Load $=(\mathrm{W} \times \mathrm{L}) \times(\mathrm{L} / 2)$

$\Rightarrow \quad\left(\left(3.69 \times 10^{5}\right) \times(0.4)\right) \times(0.4 / 2)$

Point Load $(\mathrm{W})=29520 \mathrm{KN}=29.52 \times 10^{3} \mathrm{KN}$.

Thus Moment $(\mathrm{M})=\mathrm{W} \times$ Length

$M=29520 \times 0.4$

$\Rightarrow 11,808 \mathrm{KN} / \mathrm{M}$

Moment $(\mathrm{M})=11,808 \times 10^{3} \mathrm{~N} / \mathrm{m}$

Thus Bending Moment,

$$
\begin{aligned}
& \sigma_{b}=\left(11,808 \times 10^{3}\right) \times(0.003) / 0.54 \\
& \sigma_{b}=65,600 \mathrm{~N} / \mathrm{m}^{2}=65.6 \times 10^{3} \mathrm{~N} / \mathrm{m}^{2}
\end{aligned}
$$

Where,

The Allowable Bending Stress $\left(\sigma_{b}\right)$,

$$
\begin{aligned}
& \left(\sigma_{b}\right)=220 \mathrm{Mpa} \\
& 1 \text { Pascal }=1 \mathrm{~N} / \mathrm{m}^{2} \\
& \text { Mega Newton }=10^{6} \\
& \left(\sigma_{b}\right)=220 \times 10^{6} \mathrm{~N} / \mathrm{m}^{2}
\end{aligned}
$$

Hence,

$$
65.6 \times 10^{3} \mathrm{~N} / \mathrm{m}^{2}<220 \times 10^{6} \mathrm{~N} / \mathrm{m}^{2}
$$

The Bending Stress Is Less Than The Allowable Bending Stress.

Thus, the Design for Connecting Rod (Rectangular Bar) Is Safe. 


\subsection{SPECIFICATIONS OF THE SLIDER CRANK MECHANISM}

Specifications of the Slider Crank Mechanism

- Length of the Connecting Rod $(1)=600 \mathrm{~mm}$

- Radius of the Crank (r) $=150 \mathrm{~mm}$.

Based on 1/r Ratio up to $=3$ To 5 .

Where,

$$
1 / \mathrm{r}=400 / 100=" 4 "
$$

Hence, It Satisfies the 1/r Ratio.

\subsection{SCHEMATIC DIAGRAM}

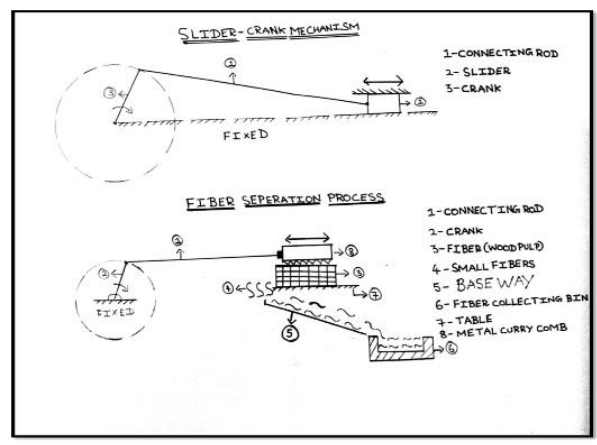

Figure. 2: schematic diagram

\subsection{SOLIDWORKS DESIGN MODEL}

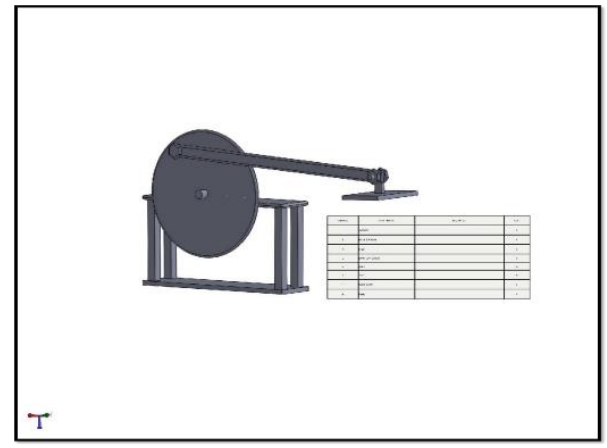

Figure. 3: solidworks design model 


\subsection{FABRICATION SETUP}

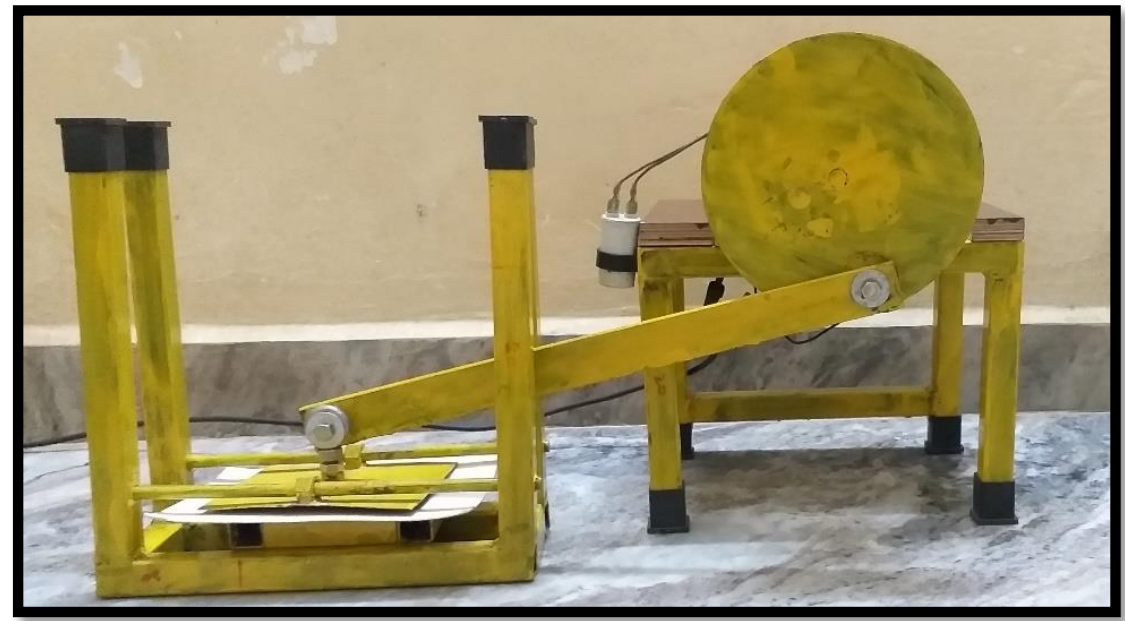

Figure. 4: fiber separation machine

\subsection{FIBER SEPARATOR TOOL}

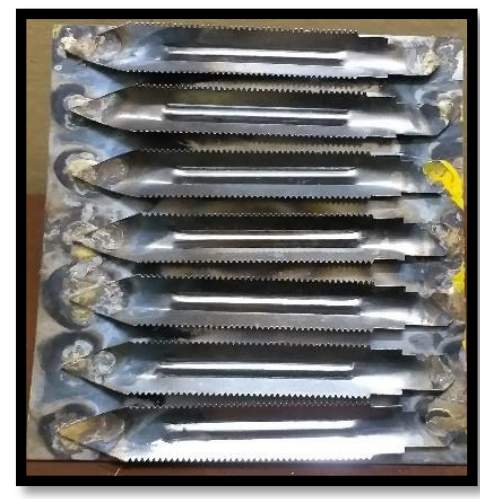

Figure. 5: fiber separating tool (made up of stainless steel) 


\section{WORKING MECHANISM}

\subsection{SLIDER - CRANK MECHANISM}

\section{$\underline{\text { First - Inversion }}$}

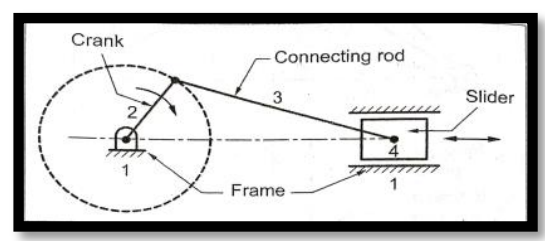

Figure. 6: first - inversion

Link -1 is Fixed

Link -2 Rotates

Link - 3 Oscillates

Link - 4 Reciprocates

$\square \quad$ It is used to convert the reciprocating motion into rotary motion.

Example: - Steam Engine.

\subsection{WORKING-PRINCIPLE}

- It is based on the SLIDER-CRANK MECHANISM (FIRST- INVERSION).

- It is used to convert the reciprocating motion into rotary motion.

- Example: - Steam Engine.

- The working of the fiber separation machine is used to separate fiber from the wood pulp (slidercrank) by using the metal curry comb we can separate the fiber from the wood-pulp.

- Where the comb is made by cutting the sharp-edges of the peeler, and by using tig-welding we can weld the sharp-edges on the stainless steel plate.

- In which the comb is operated by the use of connecting rod.

- By the use of circular disc connected to the motor which runs at a specific speed, where the small fibers are passed through the base way and it is collected in the fiber collecting bin. 


\section{RESULTS AND DISCUSSION}

In this, the fibers are produced from the wood pulp by using slider crank mechanism and the photographic images of the final product are produced here,
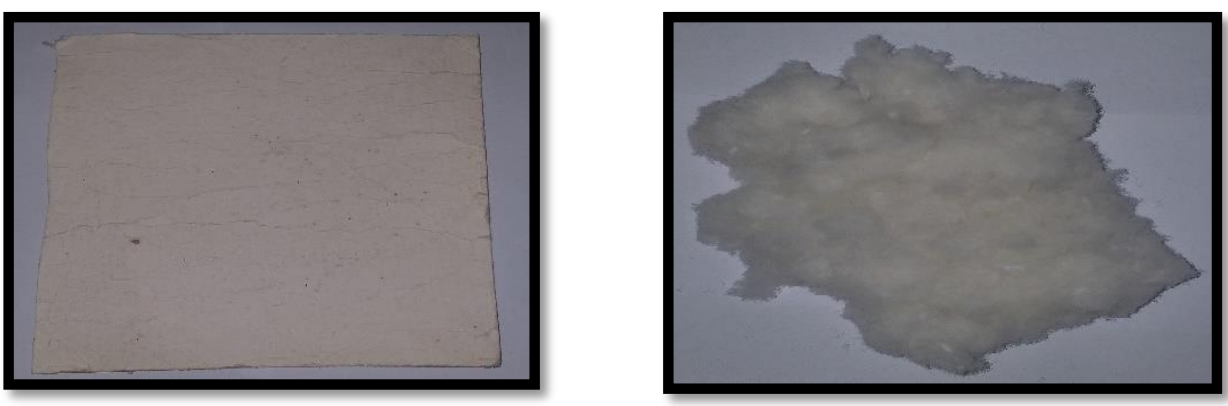

Figure. 7: left side shows the wood pulp (raw - material) image and the right side shows the image of the final output of the wood pulp (raw - material) in small fiber form.

\subsection{COST ESTIMATION}

The cost for manufacturing the fiber separating machine is produced in the tabular column format where, the cost for manufacturing the machine is reduced and displayed here,

\begin{tabular}{lcc}
\hline COMPONENTS & QUANTITY & AMOUNT (RS.) \\
\hline SS PLATE & 1 & 50 \\
\hline MS SQUARE PIPE & 1 & 525 \\
\hline MS DISC \& SOLID BAR & 1 & 150 \\
\hline SS PEELER & 7 & 70 \\
\hline MOTOR & 1 & 400 \\
\hline BUSHES, NUTS AND & AS PER REQUIRED & \\
BOLTS & & 300 \\
\hline ARC WELDNG, & AS PER REQUIRED & 100 \\
CUTTING & & \\
\hline 200ML PAINTS AND & AS PER REQUIRED & \\
BRUSH & & \\
\hline
\end{tabular}


OTHER EXPENDITURES

AS PER REQUIRED

100

( IT INCLUDES BUS

TRAVEL, AUTO FAIR,

PETROL CHARGES, TEA

AND SNACKS)

TOTOAL COST

Rs. 1,840

Table 4.1 Cost estimation

\section{CONCLUSION}

This Project is based on the fiber extraction machines, in big industries the extraction process is done by bulk machines but to encourage small scale industries this machine is designed in a simple way which is electrically operated and semi-automatic. The raw wood pulp is feed into the machine and fiber is the output. This fiber is not like cotton it is so different from the cotton. This types of fibers are $90 \%$ used in the napkin industry, which is a small-scale industry in many parts of the India. Mr. Arunachalam Muruganantham who is well known as the PAD MAN in our country. He created a mini machine for pad making, which creates job for women in rural India. The extracted fiber from our machine is compressed in Muruganantham's machine and finally the pad, as a finished product is created. Based on all the possibilities this device is made for small scale industries.

\subsection{FUTURE SCOPE}

The automotive industry is expected to grow by over $20 \%$ with the use of non-woven fabrics. Furthermore, India's growing economy will certainly support the growth of non-clothing fabrics such as nonwovens. In which automotive industry is one of the major sectors where nonwovens used. In automobile industry 25 kilograms of nonwovens used in thirty to forty components. Advanced Material Laboratory at Texas Tech University have been trying to find low micronaire cottons that are $33 \mathrm{~mm}$ and above in length which can be $100 \%$ recyclable materials for automobile industry. Cottons that are 3.4 or less in micronaire are heavy which brings huge loss to the cotton industry. 


\section{FUNDING}

This present work was jointly supported by Jenith Immanuel R, Harish B, and Prakash R. Funding sources were not involved in study design, data analysis and interpretation, report writing, and the decision to submit the article for publication.

\section{ACKNOWLEDGEMENTS}

Meiarul R designed and carried out the experiments, analyzed the data, discussed the results and wrote the paper.

\section{REFERENCES}

[1] Optimization of transmission angle for slider - crank mechanism with joint clearances, structural and multidisciplinary optimization, February 2009 by Selçuk Erkaya and Ibrahim Uzmay, 14 March 2008, Publisher - Research Gate, structural and multidisciplinary optimization 37(5):493-508, DOI: $10.1007 / \mathrm{s} 00158-008-0243-6$, https://www.researchgate.net/publication/225368369_Optimization_of_transmission_angle_for_slider$\underline{\text { crank_mechanism_with_joint_clearances }}$

[2] Experimental investigation of joint clearance effects on the dynamics of a slider - crank mechanism, multibody system dynamics, June 2010 by Selçuk Erkaya and Ibrahim Uzmay, 14 February 2010, Publisher - Research Gate, Multibody System Dynamics 24(1):81-102, DOI:10.1007/s11044-010-9192-0, https://www.researchgate.net/publication/225394408_Experimental_investigation_of_joint_clearance_effe cts_on_the_dynamics_of_a_slider-crank_mechanism

[3] APPARATUS FOR FORMING AIRLAID WEBS, by Charles E. Dunning, Neenah; Stanley R. Kellenberger, Appleton, both of Wis, US3825381A, United States Patent Dunning et al, Filed: Aug. 1, 1973 Appl. No.: 384,705, DOI: https://patents.google.com/patent/US3825381A/en

[4] SYSTEM FOR PRODUCING AN AIR LAID WEB, by Henning Laursen, John Mosgaard, Otto V. Nielson, Clark L. Poland, EP0168957A1, United States Patent Laursen et al, Field: Jun. 12, 1984 Appl. NO.: 619,946, DOI: https://patents.google.com/patent/EP0168957A1 